\title{
The Impact of Syrian Refugee Arrivals on Local Systems of Support in Canada
}

\author{
Rich Janzen ${ }^{1}$ (D) Kyla English Leis ${ }^{1} \cdot$ Joanna Ochocka ${ }^{1}$ \\ Accepted: 26 November 2020 / Published online: 4 January 2021 \\ (C) The Author(s), under exclusive licence to Springer Nature B.V. part of Springer Nature 2021
}

\begin{abstract}
This article reports on the findings of a 10-month study designed to collaboratively explore the impact of the arrival of Syrian refugee newcomers in 2015-2016 on the way local communities support newcomers. Waterloo Region, a mid-size urban centre in Ontario, Canada, was the focus of study. The study used a mixed-method design involving four methods (document review, key informant interviews, organisational survey focus groups). Findings are presented following a systems change analytical framework that included (1) an emerging vision for local refugee support in the Waterloo Region, (2) the adaptation of local structures, (3) the emergence of collaborative processes and (4) an overall assessment of impact. Three main lessons are discussed. The first lesson demonstrates how local systems change is negotiated within a broader migration landscape (contextualizing local systems change). The second lesson acknowledges that a community's historical migration response can be a springboard for local change (initiating local systems change). The third lesson suggests that expanding and coordinating community engagement in the refugee support system is integral for lasting change (sustaining local systems change). Combined, these lessons provide a comprehensive analysis into how local communities can be adaptive in supporting refugee newcomers.
\end{abstract}

Keywords Syrian refugees $\cdot$ Refugee resettlement $\cdot$ Systems change $\cdot$ Community-based research

\section{Introduction}

Canada has a history of accepting refugees. From loyalists and escaped slaves arriving in the late 1700 s and 1800 s, to subsequent waves of refugees admitted throughout the 20 th and 21 st centuries, Canada has a tradition of accepting those fleeing homelands in

Rich Janzen

rich@communitybasedresearch.ca

1 Centre for Community Based Research, Renison University College at the University of Waterloo, 190 Westmount Road North, Waterloo, Ontario N2L 3GC, Canada 
fear of persecution (Epp 2017). In 1976 Canada created a special class for refugees, separating newcomers who are admitted on humanitarian grounds from those on economic grounds and through family reunification. Between 2010 and 2017, 12\% of all newcomers to Canada were refugees, ranging from 23,000 to 58,000 each year (IRCC 2019a). The majority arrive through a proactive resettlement stream that identifies refugees overseas through three major categories: government-assisted refugees (GARs), privately sponsored refugees (PSRs) and the newer and smaller shared sponsorship programs (i.e. Blended Visa Office-Referred-BVOR; Joint Assistance Sponsorship-JAS). Others come through the reactive asylum stream as refugee claimants who seek asylum after arrival (IRCC 2017a).

While Canada's history includes numerous examples of being 'unwelcoming' and exclusionary to refugees (see CCR 1996; Scotti 2017), as well as the forced internal displacement and persecution of Indigenous people in Canada (Denov and Campbell 2002), the acceptance of refugee newcomers on humanitarian grounds has remained an enduring component of Canada's national immigration strategy (El-Assal 2015). Over time, the country has developed a support system that aids refugee newcomers in their resettlement. For example, federal policy ensures that resettled refugees are financially supported for 1 year (whether by the government for GARs or by private sponsors for PSRs). In addition, there are local community-based supports available to refugee newcomers, including some for refugee claimants. These supports range from informal groups, ethnic associations and faith communities to more professionalised service provider organisations. Service provider organisations are funded by different levels of government, foundations and private donations, some serving only refugee newcomers (resettlement services), while others also serve other newcomers (settlement services) and/or residents (public services). The federal government alone allocates about $\$ 700$ million each year to support 500 newcomer service provider organisations nationwide (SCCI 2016). From the federal government's perspective, this system of support is expected to help refugee newcomers succeed in their new life in Canada and contribute to nation-building (IRCC 2019b).

The arrival of just over 40,000 Syrian refugees to Canada between November 2015 and January 2017 represented a challenge to the established system of support in local communities. Community leaders across the country needed to respond quickly to refugee newcomers arriving at levels not seen in a generation (Conference Board of Canada 2016). They did not have the luxury of adequate planning, nor was there certainty that their community would rise to the resettlement challenge. Local leaders were instead placed in a reactive position. They needed to rapidly respond to high number of arrivals initiated not by directives of their own but by federal immigration policy. In many ways, it was a de-stabilizing moment within Canada's local refugee support system.

The high number and speed of Syrian arrivals to Canada was largely a product of posturing among Canada's main political parties. The Syrian civil war had begun in 2011. By July 2015, the number of Syrian refugees had swelled to four million as the United Nations was in the midst of its largest refugee aid request in history (UN News 2013). The ruling Conservative Party promised to resettle 20,000 refugees mostly through private sponsorship over a 4-year period, but only if re-elected in the country's upcoming federal election (CTVnews 2015). The Liberal Party countered with a much more ambitious plan. Entering the election with third-party status and capitalizing on the global sentiment 
emanating from the photographs of the death of Alan Kurdi, the Liberals promised a target of 25,000 Syrian refugees by the end of the year. The Liberal Party went on to win a majority government in October. The new government reached its target (albeit 2 months late) and by the end of February 2017, a total of 40,081 Syrian refugees had arrived in Canada (55\% government assisted, 36\% privately sponsored, $10 \%$ blended visa) (IRCC 2017b). Bolstered by these Syrian arrivals, Canada set a record in 2016 for the total number of refugees resettled in a calendar year $(46,700)$, surpassing the previous record in $1980(40,271)$ during the Indochinese refugee movement (UNHCR 2017).

Given such unprecedented numbers, the new government itself had predicted a destabilizing effect on local communities. Early in their mandate, the new government had admitted that 'the number and pace of refugee arrivals... will likely challenge even communities with established settlement/resettlement services and growing labour markets.' (IRCC 2016: 15). It was therefore not surprising that anecdotal stories soon surfaced across the country of resettlement and settlement services that were stretched to capacity or beyond, particularly within communities receiving government-assisted refugees (CBC 2016). Some communities even requested that the federal government temporarily halt refugee arrivals until their local services could adequately respond (The Globe and Mail 2016a). At the same time, the influx awakened a strong public response in support of refugees, with new local players joining the ranks. These players included citizen groups, educational institutions, municipalities, private businesses, labour, faith communities and more, some of whom had limited or no previous experience in assisting refugees (CCR 1996). In some jurisdictions, new activities and partnerships formed (The Globe and Mail 2016b), while other communities attempted to engage diverse players in a coordinated local strategy (e.g. City of Toronto 2016).

The arrival of Syrian refugee newcomers represents a unique opportunity to study the impact of the influx on local refugee support systems and their ability to adapt and change. Such exploration could be helpful in identifying lessons for how local communities support other refugees in the future, including identifying government policies that reinforce local systems of support.

To this end, a research study was carried out in the Waterloo Region, a mid-size urban centre (about .6 million) of three cities and four rural areas in south-western Ontario. This community was seen to be a promising case study given the presence of a well-established and functional newcomer support infrastructure, led by the region's local immigration partnership (LIP) called the Waterloo Region Immigration Partnership (WRIP) (Walton-Roberts et al. 2018). The region was also one of 36 Resettlement Assistance Program (RAP) communities in Canada equipped to receive governmentassisted refugees. Waterloo Region received at least 1630 Syrian refugees between November 2015 and the end of January 2017 (IRCC 2017b), more than a 250\% increase from previous years (Regional Municipality of Waterloo 2015). Finally, the region is known for fostering adaptive ecosystems, including those pursuing social innovation (DeepCentre 2015). By Spring 2016, refugee resettlement leaders in Waterloo Region felt that the community was ready to take stock of the local Syrian refugee response, even while newcomers continued to arrive. A research study was therefore launched as one forum to encourage systematic reflection on the community's experience in welcoming refugees. 


\section{Overview of Study}

A 10-month research study was conducted in Waterloo Region between September 2016 and June 2017. The purpose of the research was to collaboratively explore the disruptive impact of the recent Syrian refugee influx on the way local communities support newcomers. While Waterloo Region was the focus of study, it was suspected that the research would be relevant to other Canadian communities wishing to learn from their own refugee response. The project was funded through a targeted research call issued jointly by the Social Sciences and Humanities Research Council of Canada (SSHRC) and Immigration, Refugees and Citizenship Canada (IRCC).

A community-based research approach was used in the study that stressed community relevance, collaboration and action (Ochocka and Janzen 2014; Janzen et al. 2016a). Two main mechanisms helped implement this approach: (1) a communitysteering committee to guide the study, composed of major refugee-serving organisations in the region who had been at the heart of the local Syrian refugee response, and (2) adopting an ongoing knowledge mobilisation strategy that engaged practitioner and policy stakeholders via a number of written products and through national and local events, including local forums held in partnership with the Waterloo Region Immigration Partnership. Study investigators had previously collaborated with many local resettlement players and had played a leadership role in establishing the Immigration Partnership (Janzen et al. 2012a, b). While helpful in facilitating the research process, this previous investment admittedly may have influenced data analysis and therefore reinforced the importance of using the steering committee and forums to validate study results. A critical self-analysis of the community-based research approach used in this study can be found elsewhere (Janzen and Ochocka 2020). The study received ethics approval from the Community Research Ethics Office (CREO).

As Syrian newcomers first began to arrive (November 2015), the refugee support ecosystem within the region was spearheaded by the Refugee Services Action Group under the umbrella of the Waterloo Region Immigration Partnership. This group included the local Resettlement Assistance Program service provider (Reception House Waterloo Region), other refugee resettlement providers (e.g. Sanctuary Refugee Health Centre, Mennonite Coalition for Refugee Support, Welcome Home), immigrant settlement providers (e.g. YMCA, KW Multicultural Centre), private sponsorship agreement holders (e.g. Mennonite Central Committee) and regional government. Members of this Action Group formed the core of the study's steering committee. While the focus of the study was on recent Syrian refugee arrivals, this group intended to leverage learnings from the Syrian newcomers in support of all newcomers to the region, including refugees of any stream, refugee claimants and other immigrants.

Using a systems change framework (discussed below), there were four main research questions of the study: (1) What were the motivations, values and aspirations for individuals/groups involved in supporting refugees, and how (if at all) did these shift as a result of the arrival of Syrian refugee newcomers? (ecosystem vision) (2) What new players, activities/programs, partnerships and resources emerged to support refugees, and to what extent were they effectively integrated in the existing newcomer system of support? (ecosystem structure) (3) What new practices emerged to lead, plan, equip and evaluate refugee support within the community, and to what extent were these practices integrated with existing practices? (ecosystem process) (4) What was the cumulative 
impact of the changes noted above to overall system functioning? (overarching ecosystem)

The study used a mixed-method design. Specifically, four methods (document review, key informant interviews, organisational survey, focus groups) were implemented in sequence designed to build knowledge from one method to the next (Teddlie and Tashakkori 2003). The document review collated insight from local print and online sources (e.g. news articles, meeting minutes from local organisations, websites) and provided context to the local Syrian refugee response. Six face-to-face, semistructured interviews were then conducted with $11 \mathrm{key}$ informants (some individually, some in groups of two or three) who provided a 'balcony-level' view. Key informants were identified by the steering committee and represented a range of government, sponsor group and service provider perspectives. Next, an online survey was conducted from January to February 2017. The survey was sent out via the Waterloo Region Immigration Partnership to over 150 people on their database who were active in supporting Syrian refugees. In the case where multiple people worked for the same organisation, it was requested that they coordinate amongst themselves to complete only one survey on behalf of their organisation. Twenty-eight organisations responded (representing about $55 \%$ of all active organisations), as did another 10 individuals active in the response but not aligned with a particular organisation. The survey provided breadth of perspective across the community through a series of open- and closed-ended questions. Three in-person focus groups and two additional telephone interviews (14 participants total) were subsequently conducted with purposively sampled representatives of the organisations who were invited to participate in the survey. Finally, research results were presented and discussed at an open community forum organised by the Waterloo Region Immigration Partnership.

\section{Systems Change Theoretical Lens}

The study used a systems change analytical framework to understand the impact of the Syrian refugee arrivals on local resettlement systems of support. Systems change theory views components of a social system not as self-contained units but interconnected and interdependent within a dynamic and multi-layered context (Schensul 2009). A social system, therefore, can be understood as how the various components of a system (i.e. structures) function together as a whole (i.e. process) with intention (i.e. vision) (FosterFisheman and Behrens 2007; Kelly et al. 2000). The health of the system is dependent on developing and accessing resources that facilitate system functioning (Trickett 2009).

Applied to refugee newcomers, systems change theory suggests that the local refugee resettlement ecosystem cannot be understood in isolation or as a result of a single factor; rather, refugee newcomers and their families are embedded within layers of system components that can both affect and be affected by their resettlement. At the macro level, system components include those entities that influence broad societal conditions of welcome/ unwelcome, such as public policy, media and public opinion (Hinger et al. 2016). Within communities are local government, institutions, businesses, service provider organisations, ethnic, faith and sponsor groups and neighbours all with their attitudes and practices that determine how welcoming and supportive their community is to newcomers (Esses et al. 2010). At the heart of the system are refugee newcomers and their families who build new 
life in Canada, and who can be supported over time to move beyond their 'refugeeness' (Kyriakides et al. 2018) in ways that they share with other refugee newcomers (towards resettlement), with other newcomers (towards settlement and adaption), and with other permanent residents in Canada (towards integration and wellness) (seeJanzen et al. 2020 for a more complete description of the refugee newcomer system of support and its intended outcomes). A systems change framework considers how these various components and their functioning can be improved upon in order to reach desired outcomes. According to this framework, local communities can hone their role in supporting refugees by considering three dimensions: (1) the motivations, values and aspirations that provide direction for community players to support refugees (vision); (2) the programs, events and partnerships that encourage interaction among system players (structures) and (3) the actions (such as leading, planning, training and evaluating) that enable players to have influence on how the vision is being implemented (processes). Improvements in all three dimensions are required in order for transformative systems change to occur to the benefit of newcomers (Janzen et al. 2012c, 2016b; Reimer et al. 2016).

\section{Study Findings}

The study findings below are organised under headings that correspond with the main research questions and systems change requirements listed above. Within each section, cross-method themes were initially identified by the research team and further refined through discussion with the study's steering committee.

\section{Emerging Vision for Local Support}

The extraordinary scale and speed of the Syrian refugee arrivals initially triggered a desire for an 'emergency-directed response' but evolved into an emergent vision of a 'communitywide response'. Framing the local response as a state of emergency, with the centralised directives and resource allocation that this implies, was attractive at the onset to some community leaders. However, other voices were successful in quickly re-framing the vision towards a collaborative response that would require the coordinated efforts of a great many players each drawing on their own resources and expertise. In the words of one key informant, 'it quickly became very clear that to welcome so many Syrian refuges we needed to shift the vision for local support, including the shift in narrative, to the idea of a welcoming community'. According to study participants, the shift towards a vision for a communitywide response was possible because of the values that have historically defined Waterloo Region. In particular, local leaders drew inspiration from the region's oft-repeated 'barnraising' narrative. This narrative is based on the practice of the region's first European settlers, the Mennonites, some of whom to this day gather quickly to re-build a community member's barn following a fire. Barn-raising imagery was again evoked during the Syrian influx to inspire collaboration, cooperation and mutual support in the face of formidable challenge. In the words of one study participant:

It's part of our definition of our community... I don't think I've ever given up the notion that we are a community of doers and responders...It's like barn-raising, if somebody needs something, we help them. (Focus group participant) 
The region's continued support for newcomers and refugees over the years was also mentioned as a strong motivator for action. The memories of earlier migrations served as inspiration for many organisations and individuals involved in the Syrian resettlement. Survey results included several first-generation Canadians who listed their own experience of migration (and the support they received) as a motivation to support the next wave of migrants. For some, supporting newcomers was a matter of living out the values of one's faith, in keeping with the welcoming traditions of the many faith communities in the region. For others, their response was motivated by a sense of humanitarian goodwill common within the community. As one participant stated:

People are good-hearted and they want to help folks out. This is a community that accepts all newcomers, right? And has a good history of working to do that. I mean not always successfully, but you know, it was just oh gosh we've got a lot of people coming here. We better step up. (Focus group participant)

Research findings show that motivation for action was also extrinsic to the region, in reaction to a current global refugee crisis. To begin, national and local media coverage was overwhelmingly favourable to Syrian refugees. In the words of a survey respondent, '[the community was motivated by] the media showing the daily struggles of refugees fleeing Syria by boat and the civilian casualties, particularly by children'. Study participants also noted the political synergy of having federal provincial and municipal governments all making commitments in support of Syrian refugees as inspiring people to act themselves ('Federal, provincial, regional and municipal politicians came together to work together in a way that I have not seen before'). Finally, the desire to avert a crisis also motivated people to recognise that a coordinated response was quickly needed to prevent the local support system from becoming overwhelmed.

The various motivations listed above combined to create an enlarged vision and new collaborative norms for local refugee support. Community members seemed to agree that 'this was not business as usual' as something unprecedented was unfolding. Typical, methodical community planning was not going to be possible with a recognition that 'mistakes were going to be made'. Yet there generally remained a positive attitude that the community was up to the challenge - an optimism rooted in the faith that the necessary collaboration was possible. As one key informant summarised:

I think one of the strengths we've brought to it is a collaborative approach to doing things. As soon as [the Syrian arrivals] started to happen and emerge, we thought that we couldn't have people running all over the place doing their own thing. Somehow we had to bring this together. (Key informant)

\section{Adapting Local Structures}

The intensity of so many newcomers arriving in such a short period of time created a significant challenge for the community in determining how best to structure and organise itself in such a way that would facilitate successful resettlement. When the scale and pace of Syrian arrivals became clear, leaders immediately identified the community's structural inadequacies and raised concerns about overwhelming the 
existing resettlement infrastructure. For example, Reception House Waterloo Regionthe local refugee resettlement organisation for government assisted refugees - by its own admission was much too small and did not have the capacity to lead a local response on its own. The Local Immigration Partnership (WRIP) also identified its limited staff capacity in leading a coordinated response at the magnitude required. As a result, community leaders began to quickly search for an alternative structure by which to organise a response. A scan of local structures in other jurisdictions proved fruitless, finding that many other communities across Canada were also not yet clear on how to organise themselves for the anticipated Syrian arrivals.

Leaders next looked internally within the region. They first considered the pandemic response structure that the regional government had developed during the 2003 SARS crisis. This structure was designed to facilitate an emergency response involving all senior leaders of local governments via a 'control group' and having local actions implemented by experts who were centralised within the regional government (e.g. public health department). Community leaders were drawn to some elements of the pandemic response structure in responding to the arrival of Syrian newcomers, namely the high-level involvement of senior leaders (i.e. regional chair, mayors and senior bureaucrats) and the implementation of targeted activities through various working groups, all harmonised by a coordinating committee. However, they resisted the urge to re-create an emergency, crisis-management structure that would require highly centralised and directive leadership. Instead, they looked for ways to adapt the original pandemic response structure to become 'a community-owned structure' that would engage a range of existing and emerging players in response to a fluid and emerging context. In the words of one participant, 'the structure needed to harness the organic energy that was bubbling up in an organized yet flexible way'.

A second local structure was helpful in making this structural adaptation towards community engagement. The Waterloo Region Immigration Partnership (WRIP) was already coordinating immigrant-related issues within the region and had as part of its structure a range of committees and work groups dedicated to settling and integrating newcomers. These committees and work groups and their active membership (which included Reception House Waterloo Region) were therefore incorporated into the new Syrian resettlement structure. In fact, the community engagement model of the WRIP was key in providing a flexible template that encouraged the active involvement of as many people in the community as possible. Again, the theme of collaboration was strong in the research. As one participant explained, '[The new structure] set a good tone. It was a coordinated community response where all sectors played together.' Several other participants praised this structure, saying it was 'very helpful and instrumental' and '[brought] all the key sectors to the table'.

Figure 1 portrays the new structure, called the Waterloo Region Syrian Refugee Resettlement Preparedness Plan. The intention of this structure was to be flexible and engaging, attempting to marshal the collective resources within the community in response to a dynamic environment (i.e. where the number and pace of refugee arrivals, and the amount of available resources, were in flux). At the top of the structure was the control group chaired by the head of the regional government and included other municipal politicians and senior regional staff able to make action happen quickly. In the middle was the hands-on steering committee co-led by the head of Reception House Waterloo Region and a regional commissioner with little previous refugee resettlement 
involvement but with community-organizing experience. The steering committee included all chairs of the working groups and a small number of regional staff, including the head of the WRIP. One key informant reflected, '[The WRIP] participated in the steering committee meetings and in the control group meetings... Just having that bird's eye view of everything [was helpful] in making sure that nothing gets missed and connections are being made.' At the bottom of the structure were nine open working groups responsible for a range of ground-level action-similar to the WRIP structure but slightly expanded. The working groups functioned independently, designating their own mandate, membership and leadership. The glue to hold this structure together was communications led by the region's corporate communications department that funnelled information across the structure and outward to the community. According to key informants, both internal and external communication was crucial for the structure to function well, especially 'when a lot happens quickly and when there is potential for confusion or duplication'.

\section{Emerging Collaborative Processes}

A third aim of this study was to explore the processes or practices that were adopted to facilitate the vision for supporting Syrian refugee newcomers to Waterloo Region. Overall, participants identified six specific practices (listed below) that emerged in an attempt to bolster Syrian resettlement efforts.

To begin, the process of designating leadership for Syrian resettlement was identified as a critical issue even prior to the arrival of Syrian refugees. By November 2016, it became clear that the community required a considerably larger and more coordinated response than was typical. At that time, it was unclear who had the local capacity and authority to lead such a large-scale effort. As previously stated, neither the region's designated resettlement organisation nor the Waterloo Region Immigration Partnership had the capacity to take on the necessary leadership. The regional government had greater capacity but had no formal jurisdiction to play a leadership role. In the end,

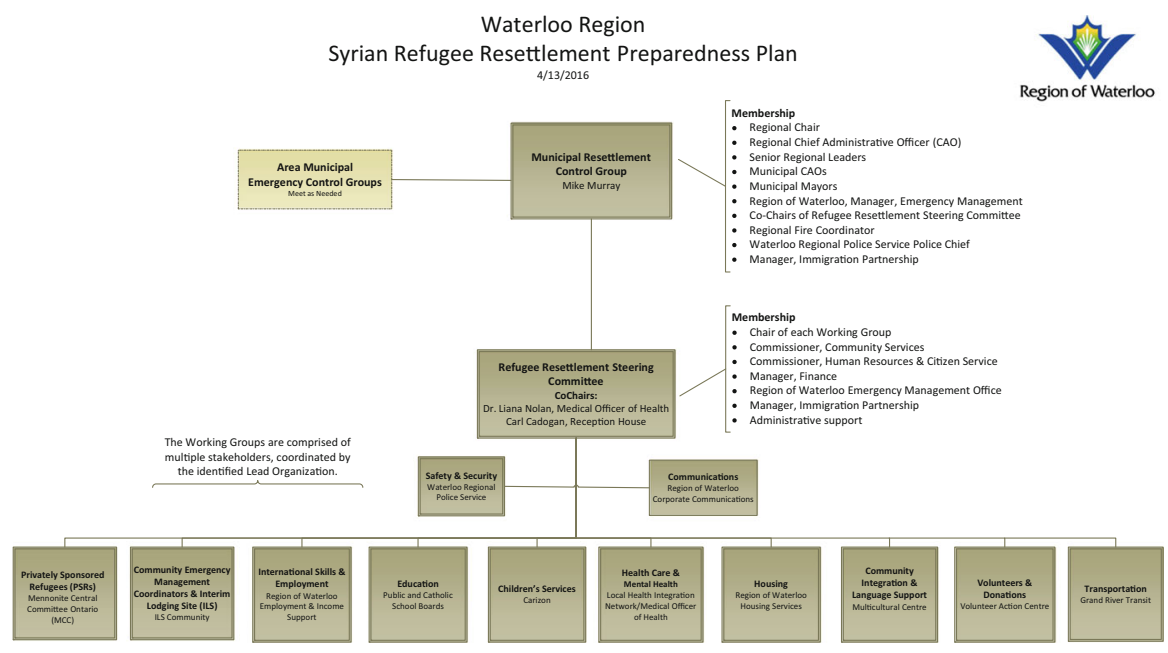

Fig. 1 The Waterloo Region structure for supporting Syrian refugees 
senior members of the regional government floated an early draft of the Syrian Refugee Resettlement Preparedness Plan (described above) to other key community players for their reaction and input. As one key informant stated: 'we realized that no one had the social license to lead this, but [we] had to ask ourselves if this [proposed structure] would resonate with other groups.' Another stated: 'This clarity [about leadership] was needed early on, as people thought things could easily spin out of control'. Within weeks, the structure was finalised, and leaders from various municipal governments and community-based organisations were designated to fill all positions.

Once designated, leaders turned their attention to promoting collaborative resettlement planning. Collaboration was primarily facilitated through the various open working groups where individuals and organisations cooperated often across sectors. When survey respondents were asked: 'What other organizations/groups were you connected with that helped you in supporting Syrian refugees?' The average number of connections identified per respondent was seven. Of these, $62 \%$ were new connections meaning that groups were working together often for the first time. As one study participant reflected, 'Waterloo Region is well known for... its ability to collaborate, but this was a level of collaboration I've never seen before.'

Closely linked to collaborative planning was the need for a coordinated communication strategy that would keep key players and the broader community informed. The process of providing accurate and up-to-date information proved to be challenging given the rapid pace of events and the ever-shifting context of refugee arrivals. Some study participants acknowledged that there was some confusion within the community as to what was unfolding, which resulted in some duplication in how newcomers were being supported. While more communication could have been done, there were still concerted efforts to provide regular system-wide communication, best described by this key informant:

[We] worked closely with regional and city corporate communications people to support the streamlining of communication so that everyone has the same information, at least on a basic level. The development of the refugee portal [\#WRwelcomesrefugees] as a place where all the information that we have available can rest for everybody was important. All the services that are available were described directly to the public, to those who were wanting to support different aspects... [There were also] regular briefing notes that were shared with all of the Immigration Partnership and all regional council and all city councils and all of the CEOs and all of the MPPs and government people looking at what the challenges and successes are, and what's coming up on the horizon. (Key informant)

Another process that supported the local response was the leveraging of local relationships and resources. Study participants mentioned how pre-existing, trusted relationships among local organisations were relied upon to develop an unprecedented response rapidly. For example, existing relationships between local Mennonite and Muslim groups were leveraged in order to sponsor Syrian families and create a system of support that was culturally and religiously responsive. In addition, the community established mechanisms to harness the outpouring of financial, human and material resources. An Immigration Partnership Fund for Syrian Newcomers was launched by 
local community foundations to disperse $\$ 400,000$ in local donations (matched by another $\$ 400,000$ from the foundations themselves) to 14 private sponsorship groups and another 19 local agencies providing 29 targeted programs. The local Volunteer Action Centre was designated to develop a system to coordinate local volunteers, the local Goodwill Store and The Salvation Army coordinated donations of clothing and household items, and Embrace Syria, an organisation operating out of the Kitchener Masjid, coordinated 'starter kits' from donations that would help Syrian families move into their first home.

While the practices listed above required the implementation of newly created processes, another theme emerged in which existing processes were actually curbed to facilitate more efficient resettlement: namely the stripping of bureaucracy. Study participants noted that local institutions were uncharacteristically flexible with their structures and mandates in order to meet the urgent needs of newcomers. In one case, the local school board bent longstanding policy and registered Syrian children without a permanent address, even sending registration staff to the hotel where newcomers were temporarily staying. In another case, the cities of Kitchener and Waterloo adjusted their leisure card access regulations so that Syrian refugee youth, living in Waterloo, could access a nearby Kitchener community centre rather than use public transit to access the closest Waterloo location. As one focus group participant explained, 'the ability to flex rules and come to new ways of doing business for me was a critical piece of learning'.

Finally, the intentionality in engaging new players emerged as a sort of overarching process to help bolster a local response. Not all people and groups felt equally engaged, and there was a need to better educate and train new players about others in the settlement sector. Still, there was a sense among study participants that the community generally did well in connecting new people and groups (notably individual citizens, volunteer groups and organisations without a primary settlement mandate) into the local refugee support system. Indeed, $73 \%$ of survey respondents $(n=34)$ agreed that 'our community did well with integrating new players into our refugee support system'.

Refugee issues that often exist under the radar were suddenly mainstream. New partnerships between formal and informal sectors, between faith and other community groups, etc. Many first-time private sponsorship groups getting intimately involved in refugee settlement - learning about many community services and supports (or the lack there of). (Survey respondent)

\section{Overarching Impact}

Findings suggest that the Syrian refugee arrivals had a disruptive but not overwhelming impact on the system of support for refugees in Waterloo Region. The number and pace of Syrian arrivals certainly challenged the community in significant ways, as we will describe below. Yet, new opportunities also led to significant and unexpected benefits (also described below). Overall, 94\% of survey respondents $(n=33)$ agreed that 'our community rose to the challenge and we can be proud of how we responded to the influx of Syrian refugees'.

In terms of challenges, participants noted a clear gap between presenting need and resources required. For example, a shortage of adequate and affordable housing, as well 
as inconsistent access to interpreters, was noted as two ongoing barriers. Organisations also faced challenges in relation to managing and leveraging the generous groundswell of support demonstrated across the community. While donations of time and other resources were vital to the success of the local resettlement strategy, it meant that organisations had to effectively utilise the support while managing expectations and dealing with greater-than-normal demand for service. Among respondents who filled out the organisational survey, $84 \%(n=21)$ felt that their organisation had experienced at least a slight amount of stress from the Syrian arrivals, with $16 \%$ experiencing 'great' or 'enormous' stress. Participants also felt that service providers were experiencing fatigue. 'Our system is set up to support [refugees], as long as we have our community partners. What we ran into was our community partners were overwhelmed, [and] it became difficult for us to run our normal approach', said one key informant.

In addition, many participants expressed concern that local resettlement efforts were creating a system of dependence among Syrian newcomers. As one focus group participant explained, 'They're dependent on us... We've grown that system for them, and they're like... I don't know how to stand on my own now, I've been wrapped around so much'. Finally, $43 \%$ of survey respondents $(n=15)$ agreed that the Syrian refugee influx deflected resources away from other refugees coming to Waterloo Region. This unequal distribution of resources 'grew a great deal of tension among all refugees' and created unease among organisations whose mandate was to serve all newcomers, regardless of country of origin.

In terms of positive impact, participants explained that arrival of Syrian newcomers unleashed many untapped resources. Eighty-five per cent of survey respondents $(n=29)$ agreed that 'we have more helpful resources to equip organizations/ groups to support refugees than we had prior to the Syrian refugee influx'. Moreover, at the heart of the local resettlement initiative was a shift towards more flexible leadership that was 'defined by the community, based on the situation in which they [found] themselves'. Within the survey, 89\% of participants $(n=31)$ agreed that 'we have stronger refugee support leadership in Waterloo Region as a result of this past year'. Beyond leadership, various community members and groups became collectively more aware of - and involved in-refugee issues. As one participant remarked, 'I think that everybody knows somebody that was involved or was part of a group of five... So, in terms of a positive disruption, the concept of what it means to be a refugee... people appreciated it... more'. Local organisations also became more involved in refugee issues. Eighty-three per cent of organisations $(n=29)$ indicated that their involvement with refugees increased over the past year, with $76 \%$ attributing this increase greatly or entirely to the arrival of Syrian newcomers.

Finally, study participants acknowledged that a significant impact of the local response was that it shifted the understanding of local refugee resettlement as being the primary responsibility of a small number of resettlement organisations to being the responsibility of a 'resettlement community'. In response to the arrivals of Syrian refugees, Waterloo Region developed a community-wide response, with numerous groups, organisations and individuals coming together to effectively welcome and integrate newcomers. As one key informant mentioned, 'What I liked was that it was a community response [with everyone] working together. No one organization owned it. No one was on their own.' (Table 1). 
Table 1 To what extent do you agree with the following statements?

\begin{tabular}{llll}
\hline & $\begin{array}{l}\text { Disagree/Strongly } \\
\text { Disagree }\end{array}$ & $\begin{array}{l}\text { Agree/Strongly } \\
\text { Agree }\end{array}$ & $\begin{array}{l}\text { Neither/Do } \\
\text { not Know }\end{array}$ \\
\hline $\begin{array}{l}\text { The Syrian refugee influx drew resources away from } \\
\text { other refugees coming to our community }(n=35)\end{array}$ & $20 \%$ & $43 \%$ & $37 \%$ \\
$\begin{array}{l}\text { We have more helpful resources to equip } \\
\text { organisations/groups to support refugees than we } \\
\text { had prior to the Syrian refugee influx }(\mathrm{n}=34)\end{array}$ & $12 \%$ & $85 \%$ & $2 \%$ \\
$\begin{array}{l}\text { We have stronger refugee support leadership in } \\
\text { Waterloo Region as a result of this past year }(\mathrm{n}=35)\end{array}$ & $9 \%$ & $88 \%$ & $3 \%$ \\
\hline
\end{tabular}

In summary, the cumulative impact of the Syrian influx was generally viewed as a positive intervention towards improving local refugee support system functioning. Many study participants expressed hope that these positive resettlement developments could be built upon in the future. Indeed, two-thirds of survey respondents agreed that the community's support of refugees would be forever changed because of the events of this past year (see Fig. 2).

\section{Discussion}

What did we learn about the impact of the arrival of Syrian refugee newcomers on local refugee support systems and their ability to adapt and change? In this section, we discuss three main lessons from Waterloo Region's local response to the arrival of Syrian refugee newcomers. These three lessons highlight different dimensions of transformative social change within refugee resettlement. The first lesson demonstrates how local systems change is negotiated within a broader migration landscape (contextualizing local systems change). The second lesson acknowledges that a community's historical migration response can be a springboard for local change (initiating local systems change). The third lesson suggests that expanding and coordinating community engagement in the refugee support system is integral for lasting change (sustaining local systems change). Combined, these lessons provide a comprehensive analysis into how local communities can be adaptive in supporting refugee newcomers.

\section{Contextualizing Local Systems Change: Negotiating Across the Migration Landscape}

The central importance of the local setting in migration and integration studies has been well documented (Glick Schiller and Çağlar 2010; McWilliams and Bonet 2015). After all, it is at the local level that everyday migration interactions take place; where refugee newcomers make efforts to resettle, work, and belong as they interface with other community members. Yet these everyday interactions do not happen in a vacuum. How a local community responds to refugees (and other newcomers) is, in part, a product of a negotiation between local realities and external frameworks which provide higherlevel direction to the flow of migration (Hinger et al. 2016; Williamson 2018). In the 


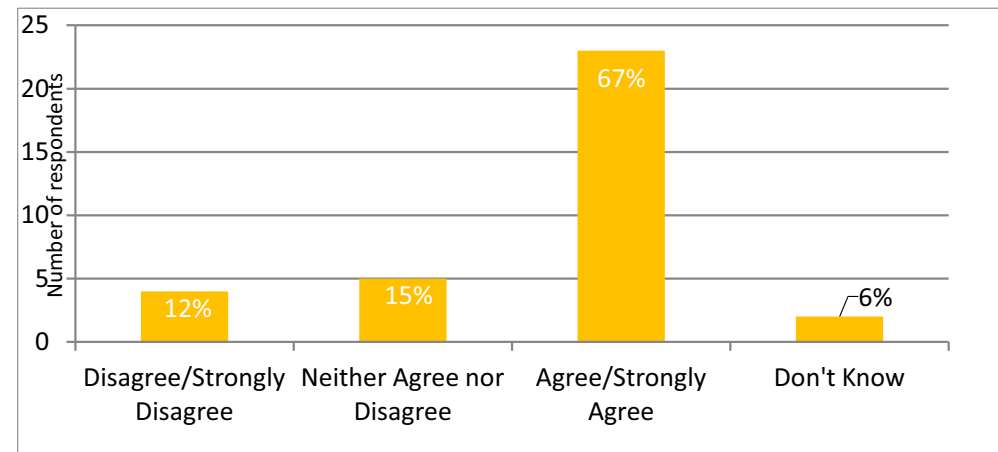

Fig. 2 The way that our community supports refugees will be forever changed because of the events of this past year $(n=32)$

language of systems theory, the local system components of refugee support are not self-contained units, but function holistically within a broader, multi-layered context (Schensul 2009).

At the onset, Waterloo Region attempted to respond to the arrival of Syrian newcomers within the context of Canada's existing national immigration strategy. Within this strategy, Immigration, Refugees and Citizenship Canada (IRCC) sets immigration targets, determines who is to be admitted and funds over 500 community-based organisations across the country to deliver general settlement services such as language training, employment counselling and social connections (SCCI 2016). These services are delivered free of charge to all permanent residents, including refugees. In addition, the federal government funds Local Immigration Partnerships (LIPs) in many communities across the country to build comprehensive partnerships involving local organisations and institutions across public, private and non-profit sectors (CIC 2011). At a lesser level, the Ontario provincial government also funds some settlement services, including funding organisations that support privately sponsored refugees (MCI 2017). At the time of the Syrian arrivals, Waterloo Region had eight organisations receiving IRCC funding (IRCC 2017b), with the regional government hosting the community's LIP (Waterloo Region Immigration Partnership).

In addition, and as previously mentioned, Canada has three refugee resettlement programs: (1) the Government-Assisted Refugees (GAR) program, (2) the Private Sponsorship of Refugees (PSR) program and (3) the newer and smaller shared sponsorship programs (i.e. BVOR and JAS). These programs determine how refugees enter Canada, their initial destination and the types of supports for which they are eligible. GARs receive up to 1 year of financial support from the government and are directed to designated communities that have an IRCC-funded Resettlement Assistance Program (RAP) service provider organisation to support their resettlement. In contrast, private sponsors assume all the costs for the initial resettlement period of PSRs upon arrival to their home community (again, usually for 1 year). Waterloo Region is a designated RAP community with about two-thirds of Syrian refugees arrivals being GARs and the remainder divided between PSRs and BVORs (IRCC 2017b).

It was within the landscape of this national immigration strategy that leaders of Waterloo Region initially considered their response to the arrival of Syrian newcomers. 
It did not take long to recognise that these previously negotiated agreements between senior levels of government and local government, organisations, and groups were inadequate for the task at hand. Local IRCC-funded organisations would be underresourced and under-staffed to provide the level of support the community had come to expect for refugee newcomers. Adequate housing for newcomers was a particular concern in Waterloo Region. While Reception House Waterloo Region was funded by IRCC to provide temporary housing for government-assisted refugees and support newcomers in their search for permanent housing, the expected surge in their caseload (about four-fold) would overwhelm their capacity. Community leaders recognised the urgent need for more affordable housing options and issued an open call which garnered a variety of responses. For example, the owner of a closed small hotel and restaurant offered and converted the empty space into transitional housing (at no cost) while 58 community volunteers kept the building staffed, all under the supervision of Reception House (Reception House 2016). Similar locally generated adaptations were needed to expand other components of the refugee newcomer system of support, such as health care and education.

Beyond adaptations of individual components of the refugee support system, a more comprehensive system adaptation was the creation of a new local resettlement structure (i.e. the Syrian Refugee Resettlement Preparedness Plan). Again, it should be noted that this structure was created and implemented without input and additional funding from senior levels of government, nor did representatives of senior levels of government meaningfully participate in that structure. One intriguing aspect of this case study, therefore, was how it revealed a deviation of the established national immigration strategy - a strategy characterised by an ongoing negotiation between local community interests and capacities, and national policy frameworks. The Waterloo Region experience showed a local community filling a gap left by the temporary breakdown of this national immigration strategy. Absent the opportunity to negotiate with federal counterparts at IRCC, the Syrian Refugee Resettlement Preparedness Plan became the designated arena in Waterloo Region for negotiation among local stakeholders. The study findings highlight the logistical challenges they faced. More importantly, the findings demonstrate how this local structure enabled community leaders towards systems change thinking as they collectively created, mobilised, and used real-time evidence to identify areas of opportunity and respond to uncertainty in adaptive and innovative ways (Suarez-Herrera et al. 2009).

It was not the first time in Canada's history that local communities initiated system adaptations within a national immigration framework. Prior to Canada's intake of Indochinese refugees in the late 1970s, it was assumed that Canada's largest urban centres were best equipped for refugee resettlement. The second-tier city of Windsor, Ontario (population about 200,000), led by local politicians and trade unionists, challenged this assumption by mobilizing its community and convincing the federal government of their resettlement capacity. The result was a new model of local refugee resettlement that was eventually embraced both by the federal government and by other mid-size urban centres (Roma 2016).

More recently, research is beginning to emerge about how other Canadian communities responded to the arrival of Syrian newcomers. These studies typically focus on various components of the resettlement experience (see Hamilton et al. 2020) or on the role of IRCC-funded Local Immigration Partnerships (Walton-Roberts et al. 2018). The 
contribution of the current study, however, is in providing insight into a system-wide local response - a response that transcended the established national immigration framework to be, in the words of one study participant, simply 'community owned'. The response demonstrated community agency to the extent that community leaders instituted system changes that were reinforced by supporting vision, structure and process. What is less clear from the Waterloo Region case example is the role of former refugees themselves (whether newcomers or those who have since settled) in influencing this systemic change. Future research could explore more in-depth the role of former refugees as co-agents in negotiating and influencing adaptations to the local refugee system of support (see Brown 2011).

\section{Initiating Local Systems Change: Leveraging a Community's History as a Springboard}

In its own post-reflection of Canada's response to the Syrian resettlement initiative, the Canadian government acknowledged that communities across the country were generally receptive to resettling Syrian refugee newcomers, yet many lacked the capacity to actually deal with the large number of newcomers in constrained timelines (IRCC 2018). As acknowledged above, Waterloo Region was no different. It did not take long for community leaders to recognise that despite initial receptivity, the community in its current configuration did not have the capacity nor infrastructure to follow through. Something new had to be done. But where to begin?

In the Fall of 2015, Waterloo Region began its response to Syrian newcomers by leveraging the community's own history as a springboard for adapting its system of refugee support. Indeed, how a community attracts and retains newcomers can be viewed as a historical continuum where past community practices inform successive action (Janzen et al. 2012a). The nature of the region's Syrian newcomer response could therefore be characterised as evolutionary social innovation where ecosystem innovation builds on past efforts and develops progressively in response to emerging need (Westley 2008). Below, we discuss how this innovation was evident across all three system change domains of vision, structure and process.

In terms of vision, Waterloo Region's response to the arrival of Syrian newcomers drew motivation from the aforementioned barn-raising narrative. This narrative of collaboration and mutual support had been previously invoked within the immigrant settlement sector, most notably in developing the cross-sectoral Waterloo Immigrant Employment Network (WRIEN) and the subsequent Waterloo Region Immigration Partnership (Janzen et al. 2012a, b). During the Syrian refugee influx, once again the barn-raising narrative provided grounding for a 'yes we can' optimism in the face of challenge. The innovation lay in expanding the trajectory of this narrative to envision an even broader and more coordinated community refugee resettlement response.

In terms of structure, Waterloo Region drew on two very different structures to create a new structure for Syrian refugee resettlement. The region's pandemic response plan was previously developed by the regional government in anticipation of the SARS crisis but never implemented. This plan proved valuable in providing mechanisms (e.g. emergency and municipal control groups, corporate communications) to engage the full range of municipality leadership and resources on a focused, common cause. However, the pandemic plan was to be directed by the regional government within a sector 
(public health) in which it had clear jurisdiction. This was not the case for refugee resettlement where community organisations had traditionally played the lead role but lacked the resources to coordinate a Syrian refugee response of the necessary magnitude. The pandemic plan was therefore counterbalanced by elements of the Waterloo Region Immigration Partnership structure to ensure broad-based community engagement and ownership, primarily through the incorporation of open working groups which themselves were based on the Immigration Partnership's own steering groups. The innovation lay in blending these two existing structures, drawing on their respective strengths and functionally adapting them for the task at hand.

In terms of process, Waterloo Region had a 10-year history of collaborative, crosssectoral planning on immigrant settlement and integration. As alluded to above, this planning first began in 2006 with the comprehensive community initiative called the Waterloo Region Immigrant Employment Network (WRIEN), initiated by the Centre for Community Based Research and led by the Greater Kitchener Waterloo Chamber of Commerce (Janzen et al. 2012b). It was later expanded to include other issues of immigrant settlement and belonging through the Waterloo Region Immigration Partnership, among Canada's first Local Immigration Partnerships (Janzen et al. 2012b). The Syrian refugee response benefited from this prior openness to collaborative planning and the trust that it had built across stakeholders (Access Alliance 2017). The innovation lays in leveraging the existing collaborative planning processes specifically for the benefit of refugee resettlement.

In summary, the experience of Waterloo Region demonstrates that adaptations in how a community responds to refugee newcomers can be grounded in the past. While previous efforts of responding to migration could not prepare the community entirely for what was to come (hence the need for adaption), it certainly was a springboard to create the innovative transformative change necessary given the scale and speed of Syrian arrivals. In this sense, the community's response to Syrian newcomers can be viewed as part of the region's ongoing migration story. Such an analysis is similar to that of Hinger et al. (2016) have framed the community's response to large numbers of Syrian refugee arrivals not as an isolated crisis, but as part of a longer historical narrative:

The events of the summer of 2015 [in Leipzig related to the arrival of Syrian refugees] can in some ways be understood as extraordinary. Norms and practices of accommodation were renegotiated, and new actors became part of the negotiation process. Yet, what we have described above had not been a fixed setting or a status quo that was suddenly challenged or ruptured by a 'crisis'. In line with our theoretical reflections, we have rather attempted to show that the negotiations and conflicts of August 2015 must be read as part of ongoing negotiation processes or, differently put, as part of the continuous production of asylum in Leipzig. (p 453)

A limitation of the current study was that it did not probe for negative aspects of the community's migration response history. Community leaders were generally positive in how they understood and self-articulated their community's story and subsequently emphasised these positives when building a local Syrian newcomer response. In response to the growing Black Lives Matter movement in the USA and globally, there has recently been much greater attention on exposing and addressing local systemic 
racism, hate crimes, discrimination and social exclusion that are also a part of the Waterloo story (e.g. Russel 2020). Further research is needed to better understand how these past and current negative aspects of the community can be used as motivation for positive system adaptation in refugee newcomer support.

\section{Sustaining Local Systems Change: Expanding and Coordinating Community Engagement}

A third lesson about transformative social change within refugee resettlement relates to sustainability. In Waterloo Region, many changes were made in a short period of time in response to newcomer arrivals unprecedented in Canadian history. Moving forward, the questions subsequently being asked are: what is the 'new normal' for refugee resettlement in our community? Which of the new structures and processes will remain to sustain the level of community of support for refugee newcomers? From the standpoint of social system theory, answers to these questions are linked to scale and coordinated adaptation.

In terms of scale, sustainable social transformation requires society-wide application (Phills et al. 2008) that is made more likely when the uptake of systems change crosses multiple social boundaries, engaging more and different people, organisations and networks across scales, from local to regional to national (Westley 2008). The large number of Syrian arrivals to Waterloo Region resulted in a wide cast of local players being engaged. Initially, the core of the region's Syrian refugee response began with those local groups formally connected to the national immigration strategy (i.e. government-funded settlement organisations, the RAP service provider, private sponsor groups and the Waterloo Region Immigration Partnership sponsored by the regional government). However, very quickly, new players and resources emerged to become equally central to the response, including: (1) established organisations providing leadership for the various work groups (e.g. the local school board, Volunteer Action Centre, Carizon, KW Multicultural Centre), (2) volunteer-driven groups providing culturally- and religiously-sensitive support (e.g. Embrace Syria, ShamRose for Syrian Culture, Muslim Social Services), (3) local community foundations administering private donations to establish the community's own resettlement fund and (4) senior local municipal leaders that activated their respective municipal bureaucracies.

The scale of engagement, however, was not limited to those groups who directly supported Syrian newcomers. Consistent with the findings of Williamson (2018), Waterloo leaders had a dual focus of attending to aid newcomers, and also attending to increasing local public acceptance towards newcomers more generally. For example, three local organisations (Mennonite Central Committee, Reception House Waterloo Region, and Mennonite Coalition for Refugee Support) who support privately sponsored, government-assisted and refugee claimants respectively, jointly organised an open community event called 'Three lanes of the refugee highway'. Their intention was to leverage the sudden interest in Syrian newcomers towards a broader community vision of welcoming all refugees and other newcomers. The challenge for Waterloo Region will be to keep engaging both those new players who supported the Syrian response as well as favourable public opinion in the long term. In other words, aiming for scale alone is not sufficient to ensure sustainability. There is another important ingredient: coordinated adaptation. 
Sustainable systems change can be understood through the lens of the adaptive cycle (Gunderson and Holling 2009). This cycle suggests that resilient and lasting systems (including social systems) are those which go through multiple and continuous stages of growth, accumulation, restructuring and renewal. It is the restructuring and renewal stages that are of critical importance in releasing resources and exploring how the system can be reorganised in the face of disruptive forces and changing contexts. During this stage, the importance of leadership emerges in determining and maintaining vital system functions that will continue to carry the system forward. Waterloo Region stands within the renewal stage vis-à-vis refugee resettlement now that refugee arrivals have returned to more typical levels. The goal will be to re-orientate the local refugee resettlement system, building on but not returning to the same resettlement vision, structures and processes that existed prior to the arrival of Syrian refugees (Fath et al. 2015).

Time will tell what elements of Waterloo Region's Syrian response will support refugee newcomers in the long term. But the sustainability of these elements will surely be linked to the ability of the community to develop a local strategy to coordinate renewal. A key mechanism in facilitating such renewal will be the region's Local Immigration Partnership (WRIP). Indeed, Walton-Roberts et al.'s (2018) study of the role of Local Immigration Partnerships during the Syrian refugee response in Ontario highlighted their importance in engaging the community through coordinated multistakeholder tables. According to their findings, successful coordination depends on how embedded the Local Immigration Partnerships are in the local community with local leaders and LIP personnel being able to build and enhance local stakeholder networks. In other words, sustainability rests not only in expanding community engagement (scale) but also in better coordinating those who are negotiating adaptative changes (coordinated adaptations). Further research could track to what extent the adaptive changes (that local communities made during the influx of Syrian newcomers) are carried forward, and what specific factors facilitate and inhibit these adaptations in the long term.

\section{Conclusion}

In this article, we described lessons learned from Waterloo Region, a mid-sized community in Ontario, which responded to the arrival of Syrian refugee newcomers in 2015-2016. The three lessons highlight different dimensions of transformative social change within local refugee resettlement. The first lesson demonstrates how local systems change, typically negotiated within a broader national migration landscape, and in this case was community owned. The second lesson acknowledges that a community's historical migration response can be a springboard for local change, while the third lesson suggests that expanding and coordinating community engagement in the refugee support system is integral for sustainability.

Combined, the lessons provide a comprehensive analysis into how local communities can be adaptive in supporting refugee newcomers. These lessons could be transferability to other mid-size communities, particularly those with Local Immigration Partnerships or other similar multi-sectoral coordinating networks. Finally, these lessons can be reinforced by senior levels of government. To this end, steering committee 
members and researchers of this study collaboratively developed and circulated a policy brief. This policy brief details eight major actions that provincial and federal departments can undertake to ensure that the lessons of 2015-2016 will not be lost for future refugee resettlement (see CCBR 2017).

\section{References}

Access Alliance (2017). Refugee health and resettlement: lessons learned from the Syrian response. Retrieved from: http://accessalliance.ca/wp-content/uploads/2017/06/SyrianResettlement_ResearchHighlightsReport_ 2017.pdf

Brown, H. E. (2011). Refugees, rights, and race: how legal status shapes Liberian immigrants' relationship with the state. Social Problems, 58(1), 144-163.

Canadian Broadcasting Corporation (CBC) (2016) Refugee agencies making headway in housing Syrians, but thousands still need homes. Retrieved from: http://www.cbc.ca/news/canada/refugees-housing-movingin-1.3476893.

Canadian Council of Refugees (CCR) (1996) An uncertain welcome: refugees at Canada's Visa Posts. Retrieved from: http://ccrweb.ca/en/uncertain-welcome-refugees-canadas-visa-posts.

Centre for Community Based Research (CCBR) (2017). Policy Brief: The Impact of Syrian Refugee Influx on Local Systems of Support. Waterloo, ON. Retrieved from: http:/www.communitybasedresearch.ca/ resources/700/Policy\%20Brief\%20June\%202017.pdf.

Citizenship and Immigration Canada (CIC). (2011). Local immigration partnerships handbook. Retrieved from: http://tamarackcommunity.ca/downloads/index/Local-Immigration-Partnerships-Handbook.pdf.

City of Toronto. (2016). City of Toronto Refugee Resettlement Program - progress report. Retrieved from: http://www.toronto.ca/legdocs/mmis/2016/cd/bgrd/backgroundfile-90733.pdf.

Conference Board of Canada. (2016) 2016: A record-setting year for refugee resettlement in Canada? Retrieved from: http://www.conferenceboard.ca/commentaries/immigration/default/16-02-02/2016_a record-setting_year_for_refugee_resettlement_in_canada.aspx.

CTV News. (2015). Harper pledges to bring 10,000 more refugees from Syria, Iraq. Retrieved from: http:// www.ctvnews.ca/politics/election/harper-pledges-to-bring-10-000-more-refugees-from-syria-iraq-1. 2510033.

DeepCentre. (2015). Building Resilience: Innovation Ecosystems as the Foundations for Growth in the $21^{\text {st }}$ century. Waterloo: Waterloo Innovation Summit.

Denov, M., \& Campbell, K. (2002). Casualties of aboriginal displacement in Canada: children at risk among the Innu of Labrador. Refuge: Canada's Journal on Refugees, 20(2), 21-33.

El-Assal, K. (2015). Why does Canada accept refugees? Conference Board of Canada. Retrieved from http:// www.conferenceboard.ca/commentaries/immigration/default/hot-topics-in-immigration/2015/01/21/ Why_Does_Canada_Accept_Refugees.aspx.

Esses, V. M., Hamilton, L. K., Bennet-AbuAyyash, C. \& Burstein, M. (2010). Characteristics of a welcoming community. Welcoming Communities Initiative - Citizenship and Immigration Canada. http://p2pcanada. ca/wp-content/uploads/2011/09/Characteristics-of-a-Welcoming-Community-11.pdf.

Fath, B. D., Dean, C. A., \& Katzmair, H. (2015). Navigating the adaptive cycle: an approach to managing the resilience of social systems. Ecol Soc, 20(2), 24. Retrieved from. https://doi.org/10.5751/ES-07467200224.

Foster-Fisheman, P., \& Behrens, T. (2007). Systems change reborn: rethinking our theories, methods, and efforts in human services reform and community-based change. American Journal of Community Psychology, 39(3), 191-196.

Glick Schiller, N., \& Çağlar, A. (2010). Locating Migration: Rescaling Cities and Migrants. Ithaca: Cornell University Press.

Gunderson, L. H., \& Holling, C. S. (2009). Panarchy: Understanding Transformation in Human and Natural Systems. Island Press.

Hamilton, L., Veronis, L., \& Walton-Roberts, M. (2020). Refugee and Forced Migration Studies Series. Kingston: McGill-Queen's University Press.

Hinger, S., Schafer, P., \& Pott, A. (2016). The local production of asylum. Journal of Refugee Studies, 29(4), 440-463 Special issue: Refugee migration and local determinations: New insight into European localities. 
Immigration, Refugees, and Citizenship (2016). Setting the context: Syrian refugee resettlement in Canada. Slide presentation for SSHRC-IRCC webinar, March 30, 2016.

Immigration, Refugees and Citizenship Canada. (2017a). Refugees. Retrieved from http://www.cic.gc.ca/ english/refugees/canada.asp.

Immigration, Refugees and Citizenship Canada (2017b). \#WelcomeRefugees: Key Figures. Retrieved from: http://www.cic.gc.ca/english/refugees/welcome/milestones.asp\#popup $1 \backslash$.

Immigration, Refugees, and Citizenship Canada. (2018). Operation Syrian refugees: an overview of Canada's resettlement initiatives and early outcomes. Retrieved from https:/www.uts.edu.au/sites/default/files/ article/downloads/Umit\%20Kiziltan.Canada.Operation\%20Syrian\%20Refugees.pdf.

Immigration, Refugees, and Citizenship Canada. (2019a). Facts and figures 2017: immigration overview permanent residents. Retrieved from https://open.canada.ca/data/en/dataset/082f05ba-e333-4132-ba42$72828 \mathrm{~d} 95200 \mathrm{~b}$.

Immigration, Refugees, and Citizenship Canada. (2019b). Annual Report to Parliament on Immigration 2018. Ottawa, ON

Janzen, R., \& Ochocka, J. (2020). Assessing excellence in community-based research: lessons from research with Syrian refugee newcomers. Gateways: International Journal of Community Research and Engagement, 13(1). https://epress.lib.uts.edu.au/journals/index.php/ijcre/article/view/7037.

Janzen, R., Walton-Roberts, M., \& Ochocka, J. (2012a). Waterloo Region. In C. Andrew, J. Biles, M. Burstein, V. M. Esses, \& E. Tolley (Eds.), Immigration, Integration And Inclusion in Ontario Cities (pp. 131-157). Montreal PQ and Kingston: McGill-Queen's University Press.

Janzen, R., Seskar-Hencic, D., Dildar, Y., \& McFadden, P. (2012b). Using evaluation to shape and direct comprehensive community initiatives: evaluation, reflective practice, and interventions dealing with complexity. Canadian Journal of Program Evaluation, 25(2), 61-88.

Janzen, R., Chapman, M., \& Watson, J. (2012c). Integrating immigrants into the life of Canadian urban Christian congregations: Findings from a national survey. Review of Religious Research, 53(4), 441-470.

Janzen, R., Ochocka, J., \& Stobbe, A. (2016a). Towards a theory of change for community-based research projects. The Engaged Scholar Journal: Community-engaged Research, Teaching, and Learning, 2(2), 44-64.

Janzen, R., Stobbe, A., Chapman, M., \& Watson, J. (2016b). Canadian Christian churches as partners in immigrant settlement and integration. Journal of Immigrant and Refugee Studies, 14, 390-410. https:// doi.org/10.1080/15562948.2015.1123792.

Janzen, R., Enns, T., Yang, L., Jun, S., Taylor, M., Ochocka, J., Notwell, J., \& Rezvani, S. (2020). Outcome Inventory: Evaluating Refugee Programs. Waterloo: Centre for Community-Based Research Retrieved from: https://www.eval4refugee.ca/indicator-inventory.

Kelly, J., Ryan, A., Altman, B., \& Stelzner, S. (2000). Understanding and changing social systems: an ecological view. In J. Rappaport \& E. Seidman (Eds.), Handbook for Community Psychology (pp. 133-160). New York: Kluwer Academic/Plenum Publishers.

Kyriakides, C., Bajjali, L., McLuhan, A., \& Anderson, K. (2018). Beyond refuge: contested orientalism and persons of self-rescue. Canadian Ethnic Studies, 50(2), 59-78.

McWilliams, J. A., \& Bonet, S. W. (2015). Refugees in the city: the neighbourhood effects of institutional presence and flexibility. Journal of Immigrant and Refugee Studies, 13(4), 419-438.

Ministry of Citizenship and Immigration Ontario (2017). Ministry website. Retrieved from: https://www. ontario.ca/page/ministry-citizenship-and-immigration.

Ochocka, J., \& Janzen, R. (2014). Breathing life into theory: illustrations of community-based research hallmarks, functions, and phases. Gateways: International Journal of Community Research and Engagement, 7, 18-33.

Phills, J. A., Deiglmeier, K., \& Miller, D. T. (2008). Rediscovering social innovation. Stanford Social Innovation Review, 6(4), 34-43.

Reception House Waterloo Region (2016). Responding to the Global Call for Refugee Support Syria and Beyond. Annual Report. Retrieved from: https://receptionhouse.ca/wp-content/uploads/board/Digital_ Annual_Report_2015_16.pdf.

Regional Municipality of Waterloo (2015). Immigration partnership update on incoming Syrian refugees and community preparedness efforts. Report IPP-15-01. File Code A02-40. November 17, 2015.

Reimer, S., Chapman, M., Janzen, R., Watson, J., \& Wilkinson, M. (2016). Christian churches and immigrant support in Canada: An organizational ecology perspective. Review of Religious Research. https://doi.org/10.1080/15562948.2015.1123792.

Roma, G. (2016). The Indochinese refugee movement: an exploratory case study of the Windsor experience. Refuge: Canada's Journal on Refugees, 32(2), 81-89. 
Russell, R. (2020). Looking at Systemic Injustice and anti-Black Racism in the Waterloo Region. The Cord: Wilfrid Laurier University Retrieved from: https://thecord.ca/looking-at-systemic-injustice-and-antiblack-racism-in-the-waterloo-region/.

Schensul, J. (2009). Community, culture and sustainability in multilevel dynamic systems intervention science. American Journal of Community Psychology, 34(3/4), 232-240.

Scotti, M. (2017). Is Canada's reputation as a safe haven for refugee's deserved? Global News. Retrieved from: https:/globalnews.ca/news/3502905/is-canadas-reputation-as-a-safe-haven-for-refugees-deserved.

Standing Committee on Citizenship and Immigration. (2016). After the Warm Welcome: Ensuring that Syrian Refugees Succeed. House of Commons Canada. Retrieved from: http://publications.gc.ca/collections/ collection 2016/parl/xc64-1/XC64-1-1-421-7-eng.pdf.

Suárez-Herrera, J. C., Springett, J., \& Kagan, C. (2009). Critical connections between participatory evaluation, organizational learning and intentional change in pluralistic organizations. Evaluation, 15(3), 321-342.

Teddlie, C., \& Tashakkori, A. (2003). Major issues and controversies in the use of mixed methods in the social and behavioural sciences. In A. Tashakkori \& C. Teddlie (Eds.), Handbook of Mixed Methods in Social \& Behavioral Research (pp. 3-50). Thousand Oaks: Sage.

The Globe and Mail. (2016a). Canadian cities ask for delay in refugee arrivals amid housing shortage. Retrieved from: https://www.theglobeandmail.com/news/politics/toronto-joins-vancouver-ottawa-inasking-for-break-in-receiving-refugees/article28281275/.

The Globe and Mail. (2016b). Religious institutions form unlikely partnership to aid Syrian refugees. Retrieved from: http://www.theglobeandmail.com/news/politics/religious-institutions-form-unlikelypartnership-to-aid-syrian-refugees/article29204512/.

Trickett, E. (2009). Multiple-level community-based culturally situated interventions and community impact: An ecological perspective. American Journal of Community Psychology, 34(3/4), 257-266.

UN News. (2013). UN announces largest ever humanitarian appeal for conflict-torn Syria. Retrieved from: http://www.un.org/apps/news/story.asp?NewsID=45112\#.WU068-vyvRY.

United Nations High Commissioner on Refugees (UNHCR). (2017). Canada's 2016 record high level of resettlement praised by UNHCR. Retrieved from: http:/www.unhcr.org/news/press/2017/4/58fe15464/ canadas-2016-record-high-level-resettlement-praised-unhcr.html.

Walton-Roberts, M., Veronis, L., Wayland, S., Dam, H., \& Cullen, B. (2018). Syrian refugee resettlement and the role of local Immigration partnerships (LIPs) in Ontario, Canada. IMRC Policy Points, Issue XIII, March 2018. Retrieved from: https://scholars.wlu.ca/imrc/2/.

Westley, F. (2008). The Social Innovation Dynamic. SiG Publication. University of Waterloo. Retrieved from: http://www.sosyalinovasyonmerkezi.com.tr/yayin/1020080009.pdf.

Williamson, A. F. (2018). Welcoming New Americans?: local governments and immigrant incorporation. University of Chicago Press.

Publisher's Note Springer Nature remains neutral with regard to jurisdictional claims in published maps and institutional affiliations. 